HOW Journal

Volume 27, Number 1, pages 49-67

https://doi.org/10.19183/how.27.1.516

HOW

\title{
Debates about Educational Issues: A Pedagogical Strategy to Explore Argumentative Skills in the EFL Classroom
}

\author{
Debates acerca de aspectos educativos: una estrategia pedagógica \\ para explorar las habilidades argumentativas en el salón de inglés \\ como lengua extranjera
}

\section{Duarte Infante, Ángela Vanesa ${ }^{1}$, Fonseca Velandia, Sandra Milena ${ }^{2}$ and Ramos Holguín, Bertha ${ }^{3}$}

\begin{abstract}
This article describes a pedagogical proposal, based on debates, to determine the type of arguments that pre-service English language teachers constructed at a public university in Tunja, Colombia. We implemented a series of debate workshops about educational issues. Thirteen modern languages pre-service teachers in their sixth semester participated in the debates. In each debate, we collected data through recordings, focus groups, and field notes to understand the impact of the pedagogical intervention. Findings suggest that the arguments pre-service teachers built were based on examples. In this sense, the arguments built were based on their personal experiences and their partners' opinions. We argue for the need to implement more research proposals that will contribute to the understanding and awareness of what argumentation implies.
\end{abstract}

1 Ángela Vanesa Duarte Infante is a tenth-semester student in the Foreign Language Program at Universidad Pedagógica y Tecnológica de Colombia (UPTC). She is also a member of the research group TONGUE at UPTC. angela.duarte@uptc.edu.co

2 Sandra Milena Fonseca Velandia is a tenth-semester student in the Foreign Language Program at Universidad Pedagógica y Tecnológica de Colombia (UPTC). She is also a member of the research group TONGUE at UPTC. sandra.fonseca01@gmail.com

3 Bertha Ramos Holguín holds a PhD in Education Sciences from Universidad Pedagógica y Tecnológica de Colombia (UPTC), an MA in Applied Linguistics to the Teaching of English as a Foreign Language. She is currently a researcher and an English language professor at the School of Languages at UPTC. bertha.ramos@uptc.edu.co http://orcid.org/0000-0003-4468-1402

Received: April 4h, 2019. Accepted: October 29th, 2019

This article is licensed under a Creative Commons Attribution-Non-Commercial-No-Derivatives 4.0 International License. License Deed can be consulted at https://creativecommons.org/licenses/by-ncnd $/ 4.0$ 
Ángela Vanesa Duarte Infante, Sandra Milena Fonseca Velandia, and Bertha Ramos Holguín

Keywords: argumentation, debates, educational issues, pre-service teachers.

\section{Resumen}

Las habilidades para argumentar han desempeñado un papel primordial en las sociedades actuales. Este artículo describe una experiencia pedagógica, enfocada en debates, como una manera de determinar los tipos de argumentos construidos por futuros profesores en una universidad pública en Tunja, Colombia. Trece futuros profesores de Lenguas Modernas de sexto semestre formaron parte de una serie de debates relacionados con aspectos educativos. En cada debate se recolectó información por medio de grabaciones, grupos focales y notas de campo, a fin de entender el impacto de esta intervención. Los resultados sugieren que los argumentos que los futuros profesores construyen están permeados por sus experiencias personales y la opinión de sus compañeros. Vemos la necesidad de implementar más propuestas investigativas que permitan contribuir al entendimiento y concienciación de lo que implica la argumentación.

Palabras clave: argumentación, debates, aspectos educativos, futuros profesores.

\section{Introduction}

Nowadays, education represents more than just transmitting knowledge, administering tests, and assessing grades (Miller, 1996; Narve, 2001). The need to enhance argumentative skills through education has become increasingly evident during the past 20 years. In fact, "promoting argumentative reasoning is considered to be a fundamental feature in Higher Education" (Mouraz, Leite, Trindade, Martins, Faustino, \& Villate, 2014, p. 279). From this perspective, we consider debates as a way to engage students in a dialogical relationship, as well as to develop argumentative skills.

Colombian educational policies demand that university students develop higher intellectual abilities, so that they can transfer them to their academic, professional, and personal life. Likewise, students will be able to face situations that could imply decisionmaking processes in a multicultural environment. Argumentative skills are, without a doubt, one of the abilities that future teachers need to foster. As part of their future teaching professions, they will have to make decisions that will affect their contexts.

The modern languages program at the public university where this proposal took place shares the same vision of fostering critical and argumentative skills. Undergraduates from this language teaching program are recognized as human beings who are capable of developing skills as critical thinking, socio-cultural awareness, responsibility, and consciousness of being an educator. Besides that, students are required to critically analyze information based on pertinent, relevant, and factual evidence. Given the focus of the program, implementing activities that help students develop the mentioned skills becomes necessary. According to Aguirre and Ramos (2011), "as teacher-educators we cannot expect to develop competent and 
critical future teachers if we do not promote and expose pre-service teachers to situations where they can analyze critical issues they may face in their real teaching experiences" (p. 187).

We decided to develop a pedagogical proposal of debate workshops with a group of pre-service English language teachers. We sought to understand the type of arguments they create in the workshops. By comprehending how and what types of arguments are constructed, the pre-service teachers could become more aware of their argumentative skills. As Lau (2011) stated, when one is able to understand how arguments are built, one can translate theoretical knowledge into actual ability and adopt a reflective and open-minded attitude.

\section{Conceptual Framework}

Argumentation and Argumentative Skills. In the words of Emeren, Grootendorst, and Henkemans (1996, p. 5), argumentation is a verbal and social activity of reason aimed at increasing (or decreasing) the acceptability of a controversial standpoint for the listener or reader by putting forward a constellation of propositions intended to justify (or refute) the standpoint before a rational judge. The latter means that argumentation happens when propositions need to be explained or defended by, for, or against making decisions and arriving at a conclusion.

We understand argumentation as an activity of social interaction where people assume a position in facing a controversial issue. A person can take on a perspective to persuade others by constructing a strong argument and finding commonalities. In this way, argumentation appears as a relevant element that can regulate social interaction.

A participant's main objective in a debate is to present standpoints (for or against). The quality of the argument will depend on the participant's discourse skills, which have to take into account the audience's backgrounds and interests to convince them. According to Houtlosser (2001), a standpoint is defined as a statement that other arguments try to support, rebut, justify, or refute. To clarify the role of the standpoint in argumentation, Houtlosser (2001) makes a comparison among equivalent terms, such as point of view, thesis, attitude, belief, opinion, conclusion, claim or debate proposition, which are the basis of an argument. Following the previous ideas, we use the term argumentative skills to refer to the capacity an individual has to construct solid arguments.

Argument. According to Freely and Steinberg (2009), "an argument is a set of claims in which one or more of them are put forward to offer reasons for another claim. The culmination of these claims is known as the conclusion;" (p. 150) in that sense, an argument is a set of statements that support a hypothesis. Freely and Steinberg (2009) further assert that an argument may have several premises, or it may have only one. Likewise, they present six 
Ángela Vanesa Duarte Infante, Sandra Milena Fonseca Velandia,

and Bertha Ramos Holguín

elements that compose an argument: (a) statements: conclusions, that we hope to pursue with the argument; (b) grounds of foundations: ideas or reasons that support or validate statements; (c) guarantees: proof, or evidence to support the foundation or ground; (d) additional proof: to further support the statement; (e) qualifications: to express the degree of cohesion in a statement; and (f) counter arguments: based on new evidences presented to weaken or destroy the statements presented by the other side (Freely \& Steinberg, 2009, p. 163).

Characteristics of the argument. A meaningful argument is usually guided by the conscious ways debaters choose to discuss. A valid argument is not just based on reasons and evidence; it is also founded on beliefs and values that are shared with the audience. Weston (2004) stated, "Arguments are made to support certain opinions with reasons" (p. 3). To build an argument, Weston (2004) offered rules for participants to consider during a debate. First of all, he proposed making a distinction between conclusions and premises, or reasons; the latter explains the conclusion. Secondly, ideas need to be presented in a natural order. Next, the premise that participants present should be reliable and plausible. Then, to express their standpoints in a better way, participants should use concrete and specific language employing accurate terms consistent with each idea. Finally, the conclusion and premise will be closely connected. In addition, when the participants are immersed in a debate session, they can express themselves by using different types of arguments. In this case, Weston (2004) classified arguments and presented their main characteristics, which are illustrated in the following chart.

Debates. According to Freely and Steinberg (2009), a debate is a process of inquiry and advocacy. It is a way of arriving at a reasoned judgment on a proposition. Individuals may use debate to reach a decision in their own minds. Alternatively, individuals or groups may use it to persuade others to agree with their arguments. Núñez and Téllez (2012) assert that a debate is a practice that implies generating controversy about a specific issue. The authors further explained that debates help learners improve their argumentative skills.

A debate provides reasoned arguments for and against a proposition because it requires that listeners and opposing participants comparatively evaluate competing choices. Additionally, a debate demands critical thinking. According to Parcher (1998), "debating develops research, critical thinking, evidence, problem resolution and communicative abilities. Society, like individuals, must have an effective method of making decisions; debate pervades our society at decision-making levels" (p. 2). In other words, we understand that a debate is a formal and structured discussion about an issue where three parts are involved: The first supports the main hypothesis, the second opposes the hypothesis, and the last has the objective of judging the quality of arguments and performances during the debate session. 
Debates about Educational Issues: A Pedagogical Strategy to Explore Argumentative Skills in the EFL Classroom

Table 1. Types of arguments proposed by Weston (2004).

\begin{tabular}{|l|l|}
\hline \multicolumn{1}{|c|}{ Arguments } & \multicolumn{1}{c|}{ Characteristics } \\
\hline $\begin{array}{l}\text { Arguments based } \\
\text { on examples }\end{array}$ & $\begin{array}{l}\text { All claims are supported by plausible examples. } \\
\text { In order to prove something, using more than one example is necessary. } \\
\text { Participant needs to obtain background information and use } \\
\text { counterexamples to strengthen the argument or disprove someone. }\end{array}$ \\
\hline Analogical argument & $\begin{array}{l}\text { There is a similarity between two examples, which } \\
\text { supports one of the standpoints. } \\
\text { Analogies require a relevant example. }\end{array}$ \\
\hline $\begin{array}{l}\text { Arguments from } \\
\text { authority }\end{array}$ & $\begin{array}{l}\text { This is an argument supported by a qualified authority or a reliable source. } \\
\text { Sources should be cited and informed. } \\
\text { Sources need to be impartial. } \\
\text { Sources need to be independent, neutral, and objective } \\
\text { in their view of the position being argued. }\end{array}$ \\
\hline Causal arguments & $\begin{array}{l}\text { The relationships between two events are presented, } \\
\text { in which one is the effect of the other. } \\
\text { The argument needs to explain how the cause } \\
\text { leads to the effect and its correlation. } \\
\text { If there are many possible causes, the most likely cause must be identified. }\end{array}$ \\
\hline Deductive Argument & $\begin{array}{l}\text { Truthful premises are presented in order to obtain a reliable conclusion } \\
\text { Deductive arguments offer an effective way of organizing an argument. }\end{array}$ \\
\hline
\end{tabular}

A good debate is characterized by participants' ability to present logical and complete information to make sure the audience understands the facts. Thus, the audience must be provided with enough evidence to convince and allow them to learn and contribute to the motion of the debate. During the debate, questions may emerge, which leads to the conclusion of the presented issues. These questions must be clarified, answered, and analyzed. For the purpose of having a dynamic debate, participants' speeches should be organized in a methodological form. Additionally, a maximum time is allotted for each participant. In this sense, these aspects must contribute and respond to the requirements and necessities of the debate.

\section{The Pedagogical Proposal}

Context of the experience. This pedagogical proposal took place at a public university in Tunja, Colombia. We worked with sixth semester students, who were pursuing a degree in Modern Languages. We carried out this study with 13 students. There were 5 male and 8 
Ángela Vanesa Duarte Infante, Sandra Milena Fonseca Velandia,

and Bertha Ramos Holguín

female participants. Their ages ranged from 22 to 28 years. The name of the course in which this pedagogical proposal was implemented was English VI. The course emphasized the exploration and development of the students' communicative competence in English.

We applied an English language proficiency test at the beginning of the course. We found that the majority of the students had an intermediate level. In regard to their attitude, they were positive and active in each debate session. Despite having their own personalities, such as being extroverted or introverted, they were friendly, understanding, and respectful with each other.

Objective of the pedagogical proposal. The main objective of this pedagogical proposal was to determine the type of arguments that pre-service English language teachers constructed at a public university in Tunja, Colombia, during the implementation of workshops about current educational issues. The specific objectives were to create respectful environments to conduct in-class debates about educational issues, to promote students' participation, and to make the learning of English a more meaningful experience.

Conditions of the implementation. The implementation consisted of a series of workshops carried out with the participating pre-service English language teachers. We began by asking these participants and teachers to select the topics related to educational issues. Then, we designed the workshops. Finally, we implemented the workshops and collected data on the types of arguments constructed during the debates.

Since we involved the participants before creating the workshops, we were able to account for issues that were closer to the participants' reality. In this sense, the topics also allowed them to discuss future situations that they might face in their teaching profession. Together, we came up with the following topics for the debates: the use of guns at school, homework is harmful, gender stereotypes at school, and whether religion should be taught in public schools. Each debate was based on a workshop that lasted three hours. We encouraged the participants to take a position and participate by intervening during each session.

When designing the workshops, we made sure to use reliable sources such as news reports, articles, videos, and images. These sources came from experts on the topics. These sources also gave the participants the opportunity to contrast both sides of an idea and to make decisions and express their ideas regarding the topics. In that sense, we designed four workshops in which the participants followed five steps: pre-reading, during-reading, postreading, video analysis, and debate. These steps guided them in building their discussions from beginning to end.

The first step was called a pre-reading process analysis. In this step, we presented the topic to the participants by using pictures, texts, and videos. This helped them answer questions related to the topic, as well as analyze the information using previous knowledge. 
Additionally, they could open their minds to other possibilities and make a decision on what position they would take as the main objective of the pre-debate stage.

The second step was the during-reading analysis. After reading about the topic, the participants worked collaboratively to identify the main ideas, key words, and meanings in the text. They also discussed their own contexts and the one provided in the text. Because of this, they were allowed to reflect on the issue about which they were reading. In this order of ideas, they were contextualized enough to express their opinions and their thoughts to their partners, as well as to recognize their partners' ideas in the construction of their arguments.

The third step was the post-reading analysis. In this step, the participants were allowed to make inferences regarding the topic and compare their standpoints. This helped them answer some of the questions they had posed before and during the reading. Their inferences were based on their own background knowledge, as well as some factual information that was useful in the next step.

The fourth step was a video analysis. We played a video related to the topic, keeping in mind that it had to come from a reliable source. This gave the participants the opportunity to analyze the topic from a different perspective. At this point, they gained further awareness on the diversity of thoughts and positions one can take in regard to the same issue.

The fifth step was part of the debate step, and we called it the "Let's Debate Analysis". In this step, the participants continued to work together by answering questions that allowed them to change and/or reinforce their positions on the topic. On the other hand, each workshop presented a part for them to remember. It provided them with the essential information to argue properly, which included the concept, types and parts of an argument, key words, and expressions that corresponded to a suitable argument.

The following chart summarizes the workshops and the types of arguments that were presented.

Table 2. Workshops: Topics and types of arguments

\begin{tabular}{|c|l|l|}
\hline $\begin{array}{c}\text { Workshop } \\
\text { number }\end{array}$ & \multicolumn{1}{|c|}{ Topic } & \multicolumn{1}{|c|}{ Types of arguments } \\
\hline 1 & The use of guns at school & $\begin{array}{l}\text { Arguments based on examples/ } \\
\text { analogical arguments }\end{array}$ \\
\hline 2 & Homework is harmful & Arguments from authority \\
\hline 3 & Gender stereotypes at school & Causal arguments \\
\hline 4 & Should religion be taught in public schools? & Deductive arguments \\
\hline
\end{tabular}


Ángela Vanesa Duarte Infante, Sandra Milena Fonseca Velandia, and Bertha Ramos Holguín

Teachers' and students' roles. When the discussions took place, the teachers acted like guides and moderators. They followed the order and pace of the debate thus creating a suitable environment. The participants were encouraged to contribute actively in the debate sessions. They worked collaboratively with their partners in order to share their opinions and points of view regarding the different topics and issues. In addition, they were able to analyze the information provided by their partners and by the workshops. This aided them in building valid and effective arguments in order to defend their position and make decisions about the most relevant information. They took into account their backgrounds, values, and beliefs to answer the questions posed by the teacher and to come to agreements and conclusions. Consequently, the debate sessions were developed in a respectful and understanding environment, where all the opinions were listened to and considered relevant for the discussion.

Data analysis. We followed the steps proposed by the grounded approach (Denzin $\&$ Lincoln, 2005). The grounded approach for data treatment is considered an appropriate way to analyze and explain human behavior in social contexts. In that sense, and according to Freeman (1998), the data were collected "to look for meanings that surface through the process of naming, grouping the names into categories, and finding relationships among them" (p. 108).

We gathered the information during the course in which we applied the four workshops on educational issues. First, the information was collected through audio recording, which we transcribed. Second, we collected the observation formats of each session and its comments. Third, we applied a focus group interview, which we also transcribed at the end of the implementation. After this process, we developed an analytical framework in which we read the data several times to look for commonalities and themes or patterns (Freeman, 1998).

For this phase, we read and reread the information in the transcripts and field notes. We also underlined useful data that told us about the types of arguments that the participating pre-service English language teachers had constructed. After that, we named our initial findings, categorized them, and found relationships among them. In this way, we found that the arguments used by the participants were mainly based on examples (Weston, 2004) and, as such, they were permeated by their personal experiences and their partners' opinions.

\section{Findings}

The participating pre-service English language teachers argued based on their points of view, personal experiences, examples from their daily life, and previous knowledge about the topic. They used this kind of knowledge as a strategy to build their arguments and support their claims. It helped the participants build clearer ideas, develop understandable arguments, 
and persuade their listeners. The previous activities or steps also suggested that the participants became more conscious of what they were saying and how they were constructing their own opinions, including opportunities to bring up their personal experiences, thus, making their arguments more convincing. Miller (2011) explained this better by saying that the argument a person provides is a specific instance of a larger phenomenon. A person might use his/ her own personal experience to make wider generalization. For example, if a person is giving a speech about the need for public libraries, that person can use his/her own personal experience about using the public library, such as using the internet, checking out a book, or having a quiet place to work. Based on that personal experience (one's own data) of needing the library, the person generalizes (via reasoning) to make the argument that libraries are an important facet of the community (one's own claim).

Arguments based on examples and personal experiences. The participants became aware of the importance of using honest and personal examples to construct their arguments and defend their points of view in the debates about educational issues. The previous analysis was evidenced in the third workshop about gender stereotypes. In this debate, a participating pre-service English language teacher gave examples about the perceptions people had about women in certain careers at the university. The participant mentioned the following:

It is the same with the program degree in the university, a woman who is studying engineering. She is seen like a man...or a macho, for example. For example when a man is studying psycho pedagogy or kindergarten... Or nursery... things like that. [sic] (Participant one, Sixth semester, Second audio track, Second debate session Gender stereotypes)

In the argument above, we could observe that the participant perceived gender stereotypes using another point of view, in which the educational programs were also categorized. When he said the word "macho", he criticized the way university students and their cultures have been nurturing these stereotypes, in which women and men must act a certain way to fit into society's standards. Otherwise, they might be judged. We can then say that when the participants assumed a critical position, they were also demonstrating their critical thinking skills. By providing an argument to the current issue, this participant was breaking down barriers that society imposes on women and men to follow certain behaviors. Furthermore, this participant used "for example", which perhaps demonstrated a reference to some experience he had probably lived to support his claim. Therefore, he presented his disagreement against this imposition with the aid of his background knowledge. As Weston (2004) affirmed, a person needs to use examples to strengthen arguments.

Another sample was taken from the fourth workshop about teaching religion in public schools, where a participant states,

Ok, I studied in a private and public school, and in the private school is more, [sic] is more like a subject, because we have to take into account that before entering to [sic] a primary school, we have to follow the rules. 
Ángela Vanesa Duarte Infante, Sandra Milena Fonseca Velandia, and Bertha Ramos Holguín

Rules are imposed. For example, going to thechurch [sic]. In fact, I had to go to mass every Friday. It is like that, if you want to study in that school, you need to follow their rules not your rules, not your religion or your beliefs. [sic] (Participant two, Sixth semester, Third-audio track, Should religion be taught in public schools)

In the previous statement, the participant, based on her own experience, talked about the way religion was imposed at schools. Despite having her own position and beliefs about the topic, she emphasized the rules some schools have in regard to religion. In that sense, the participant's argument demonstrated a critical and analytical position toward the issue because she presented her position, personal experience, and information to back up her claim. As she mentioned, she was in disagreement with the educational system that infringes upon the freedom of religion to be part of an educational institution. Grootendors and Henkenmas (1996) state: a central notion of argumentation is disagreement or difference of opinion (explicit or implicit). In this sense, it can be presented as an argument (as cited in Drid, 2016, p.55).

The next argument was taken from the gender stereotypes workshop in which a participant proffered a personal experience as an example.

We see how society influences so much in children... for example, they come to the world... clear... pure, with no prejudices but then, they start dressing and behaving in certain ways depending on the places where they are. I saw that with my daughter. Now that she is at school she behaves differently, she criticize my tattoos, for example. [sic] (Participant three, Sixth semester, Third audio track, Worksheet 2, Gender stereotypes)

From the excerpt presented above, we can see that the participant emphasized the influence of society over children, who learn to build prejudices about the roles men and women perform. To support this claim, the other participants said that children came into the world clear, pure, without prejudices. The participant of the excerpt spoke from his own experience and said that the influence over children was something that everyone could see. He generalized society's influence as something bad, with which he did not agree. In this type of argument, we noticed that the participant provided a claim and a reason. According to Freely and Steinberg (2009), this is proof or evidence to support and validate statements, as with the participant, who offered reasons to support his statements, while allowing his partners to go deeper into the issue.

Arguments based on partners' opinions. According to Harrington, Lebeau and Lubetsky (1999),

The nice thing about debate is that debates lead towards a more natural discussion. First, I give my position and then you give your position, and then I would address each of the points in your position and comment on them. And then you would have the opportunity to address each point in my position and comment on it. (p. 53)

In this case, the data revealed that at the moment of arguing in the debate sessions, the participating pre-service English language teachers analyzed their partners' opinions 
to strengthen their own ideas. In the example below, a participant gave her opinion about teaching religion at school. She suggested that it should be taught in our context by example, and she emphasized that religion was imposed by society.

Instead of teaching religion we can change it to something cultural. For example, we can change that subject about religion for something like cultural awareness because religion is very close to culture. So in that way, for example, the teacher could present the characteristics, or maybe the history about religion. You can learn how religions were born and how they are represented. [sic] (Participant four, Sixth semester, Third audio recording, Should religion be taught in public schools)

In this example, the participant mentioned that religion was imposed at public schools. Additionally, she presented her own ideas about how religion should be taught. In her argument, the participant suggested that religion could be taught from a cultural standpoint since it was closely related to culture. Her ideas seemed to be based on her own experiences, such as having to learn religion as something imposed upon her. Thus, her previous knowledge helped her create her own opinion about the topic. That is why she proposed teaching cultural awareness as an argument against imposing religion as a subject. As we mentioned previously, the participant presented reasons to support her claim. According to Freely and Steinberg (2009), the counterarguments are based on new evidences presented to weaken or destroy the statements presented by the other side.

Likewise, the next example showed how another participant provided information to counter-argue.

I think that the problem is not religion but the way we teach it, because you can see it as a science, not as something that has values... that is the problem, I think that religion is very interesting as a science... you can learn a lot about it, and I think, that people are not very literate about why they don't believe in something. [sic] (Participant 6, Sixth semester, Third audio track, Should religion be taught at school)

We can observe another perspective on whether religion should or should not be taught at schools. This participant expressed her point of view in regard to how religion should be taught. We noticed that it was her opinion because she used expressions as "I think" to present her ideas. In this case, the participant compared religion to a science. One of her reasons to support her opinion was that "people are not very literate about why they don't believe in something." From this statement, the proposal to compare religion to a science emerged. For this participant, the problem with the way religion was taught could be related to how it was connected to values. She used this as a fact to support her claim. According to the Department of Communications of Pittsburgh University, facts refer to statements that can be verified. In this way, facts need to be analyzed in order for one to be able to arrive at a conclusion. In addition to analyzing the fact she proposed, she also had an open mind when it came to perceiving religion based on her own experiences. This allowed her to have her own criteria apart from the beliefs of society. 
Ángela Vanesa Duarte Infante, Sandra Milena Fonseca Velandia, and Bertha Ramos Holguín

The next argument was taken from the second workshop about homework assignments. In the following argument, a participant stated that the job of educating children corresponded not only to the teachers but also to the parents.

Yes, but education is not only at school, you as a parent you must pay attention to how your child is developing. What is important is not the tests because if you want your children to be singers or an actors, you need to reinforce that because many of these things do not happen at school. [sic] (Participant 3, Sixth semester, Fourth audio track, Homework is harmful)

In this excerpt, the participant based his argument on a reasoned opinion, where he expressed critical and personal thoughts based on logical reasoning. Taking into account that the participant (as a pre-service English language teacher) had certain knowledge that supported his argument, he expressed that the education of students was a joint effort where parents, as well as teachers, had to strive to contribute to the development of children. In relation to this argument, Weston (2004) states that the premises presented should be reliable and plausible. When the participants gave an opinion, considering their experience, it resulted in a reliable experience that allowed them to reach a decision in their own mind during the debate.

The argument below was taken from the second workshop about homework assignments. In this argument, a participant analyzed her partner's opinion in order to employ some of her standpoints to adjust her own arguments.

I agreed with Alejandra, because I think, sometimes extensive homework is unhealthy; I saw many cases. That... parents do their children's homework because sometimes children say... "I don't understand "or "I don't like homework." So they prefer to do their homework. [sic] (Participant 4, Sixth semester, Fourth audio track, Homework is harmful)

In this argument, the participant (based on her partner's opinion) showed how excessive homework could be harmful for children. The participant's argument demonstrated a critical and analytical position towards the educational issue. She, as a future teacher, understood the importance of homework. She also demonstrated her disagreement on the excessive demand (or allocation?) of home study.

\section{Conclusions}

In this pedagogical proposal, the participating pre-service English language teachers' arguments were divided into three types: examples, personal experiences, and opinions. They used these types of arguments to express their standpoints about educational issues during the debate workshops. These pre-service teachers regularly used examples as a way to establish a direct link between the topic and local context, thus achieving a more meaningful and effective communication (Pineda, 2003; Pineda, Núñez, \& Téllez, 2004). The arguments they 
built were permeated by their own experiences, e.g. examples they obtained from situations in their daily life, and the previous knowledge they had already possessed about the issue. In addition, they resorted to their partners' opinions to validate or shape their own arguments.

In terms of implications, the participants were motivated to contribute in the debate exercises. They used their own personal skills, such as communication, decision making, conflict resolution, logical thinking, understanding, reasoning, previous knowledge, life experiences, background information, and analysis. Thus, they utilized both communicative and paralinguistic elements in order to construct their own arguments. These elements were the main tools used to understand and interpret issues, which brought them closer to their own contexts.

We saw that the participants' argumentative process was influenced by their linguistic development, passive and active roles in the discussions, individual reflections, degree of educational issues awareness, relationships between each other, collaborative work, and mutual support. Because of this, each participant's argumentative process was different, which is why we became aware of the importance of valuing students' diversity. In fact, the participants' multiplicity of thoughts helped one another enrich their arguments. We also realized that a learning environment full of comradeship, understanding, and respect facilitates the communication, self-confidence, and active participation of the students. In turn, this favored the debate sessions and strengthened the participants' speaking skills.

When arguing their points of view, the participants needed to assume a position and defend it. According to the International Institution of Debate (2013), the debate offers a good environment to learn how to listen to people while learning about other topics. Based on what a participant might be defending, the others must also provide a reasonable response. We noticed this in the workshops, where the participants demonstrated reasoning and open-mindedness when they discussed their own and their partners' opinions. In fact, the classroom, in this proposal, became an ideal place to foster and establish good relationships.

Additionally, the participants had to accept the fact that their opinions were not always the right ones. These are qualities that allowed them to listen to others to complement and strengthen their own defense. Despite the fact that not all of their viewpoints were supported by facts, the participants used their own personal experiences and opinions to defend their positions. In this way, their arguments were valid because they were based on their realities.

In terms of the challenges we faced while working on this pedagogical proposal, we noticed that the participants could get emotional or heated during the debates. Thus, we believe their feelings might have interfered with their language performance and reasoning process. In this stance, we considered Harmer (2007), who highlighted the need for teachers to create a 
Ángela Vanesa Duarte Infante, Sandra Milena Fonseca Velandia, and Bertha Ramos Holguín

non-intimidating environment, motivate the participants, and engage them in learning activities to express feelings, desires, preferences, interests, and values in a respectful way.

The development of the debate sessions allowed us to notice that this is also a strategy that helps students in general to organize their thoughts and become confident when speaking. We realized that throughout the debate sessions, the participants talked more than before. However, another challenge was the fact that they had diverse English language proficiency levels. Although most of them had an intermediate level, some of them lacked confidence in speaking and taking a proactive role in the classroom. This is relevant to be considered; as teacher educators, we should not pressure or force students to express themselves, nor demand a high level of communication in the target language. This would be counterproductive to the purpose of the activity.

\section{References}

Aguirre, J., \& Ramos, B. (2011). Fostering skills to enhance critical educators: A pedagogical proposal for pre-service teachers. HOW Journal, 18(1), 169-197.

Denzin, N. K., \& Lincoln, Y. S. (2005). The Sage handbook of qualitative research. Thousand Oaks, CA: Sage.

Drid, T. (2016). The realm of argumentation: Basics and history. Kasdi Merbab University, 101. 112.

Emeren, F. H., Grootendorst, R., \& Henkemans, F. S. (1996). Fundamentals of argumentation theory: A handbook of historical backgrounds and contemporary developments. Mahwah, NJ: Erlbaum.

Freely, A. J., \& Steinberg, D. L. (2009). Argumentation and debate: critical thinking for reasoned decision making (12 ${ }^{\text {th }}$ ed.). Boston, MA: Wadsworth Cengage Learning.

Freeman, D. (1998). Doing teacher research: From inquiry to understanding. London, UK: Heinle \& Heinle Publishers.

Grootendorst, F., \& Henkemans, S. (1996). Fundamentals of argumentation theory: a handbook of historical backgrounds and contemporary developments. Retrieved from https://philpapers.org/rec/VANFOA-3.

Harmer, J. (2007). How to teach English- New Edition. Pearson Longman.

Harrington, D., Lebeau, M., \& Lubetsky, M. (1999). Discover debate: basic skills for supporting and refuting opinions. Dallas: Language Solutions.

Houtlosser, P. (2001). Points of view. In F. H. van Eemeren (Ed.), Crucial concepts in argumentation theory (pp. 27 -50). Amsterdam: Amsterdam University Press.

International Institution of Debate. (2013). Retrieved from https://www.salto-outh.net/tools/ otlas-partner-finding/organisation/the-international-institute-of-debate.12291/

Lau, J. Y. (2011). An introduction to critical thinking and creativity. Think more, think better. New Jersey: Wiley. 
Miller, J. P. (1996). The holistic curriculum. Toronto: OISE Press.

Mouraz, A., Leite, C., Trindade, R., Martins, J., Faustino, A., \& Villate, J. (2014). Skills in Higher Education: A Comparative Approach. Journal of Education \& Human Development, 3(1), 279299.

Narve, R. G. (2001). Holistic education: Pedagogy of universal love. Brandon, VT: Foundation for Educational Renewal.

Núñez, A., \& Téllez, M. F. (2012). Using debates in the classroom: A pedagogical strategy for the development of the argumentative competence in the teaching of English as a foreign language. Bogotá, Colombia: Publicaciones Universidad Externado de Colombia.

Parcher, J. (1998). The value of debate: Adapted from the report of the Philodemic Debate Society, Georgetown University. Retrieved from http://www.pbcfl.net/curriculum/coaching/60general/gc01.pdf

Pineda, C. (2003). Searching for improved EFL classroom environments: The role of critical thinking-related tasks. Bogotá, Universidad Externado de Colombia.

Pineda, C., Núñez, A., \& Téllez, M. (2004). Key aspects for developing your instructional materials. Profile: Issues in Teachers' Professional Development, 5, 128-139.

Weston, A. (2004). A rulebook for arguments ( $3^{\text {rd }}$ ed.). Indianapolis, IN: Hackett Publishing Company, Inc. 
Ángela Vanesa Duarte Infante, Sandra Milena Fonseca Velandia,

and Bertha Ramos Holguín

\section{Workshop Sample}

Student's name:

Date:

\section{TOPIC:}

Homework is harmful

Before reading:

Watch the video and answer the following questions. You can take your own experiences into account.

How could you define homework?

Do you think that homework supports the student's learning process?

Should homework be done at school?

While reading:

Work in groups. Read the following article and reflect on for and against arguments that you find in it. You can underline them if you want.

\section{Is homework a good idea or not?}

\section{Why is it a good idea?}

While giving homework to pupils in secondary schools is generally seen as a good idea, some don't think that kids in primary schools should have to do it. For the last 100 years or so, experts have been trying to work out if it is beneficial to give homework to kids in primary schools.

In the UK, the government says it's up to the head teacher to decide whether or not their school will set extra work like this. Many think that giving homework to primary school children is an important part of their learning.

They believe it helps them to practice what that they have learnt in lessons, in order to get better at things like spelling and handwriting.

They say it helps to teach children how to work on their own and be disciplined with themselves - both skills that are useful later in life. 
It can also allow parents or guardians to get involved in their children's learning.

Chris told Newsround: "If you like learning, homework helps to support your learning. It's really important to go back afterwards and think about what you're learning in class. Practice makes perfect."

Why is it not a good idea?

Some people think that giving homework to children in primary school is not necessary.

They think it puts too much pressure on them and that the time spent doing homework could be used to do other activities.

"The trouble with homework is that it gets in the way of all of those good things that you could be doing and it doesn't necessarily help you with your school work."

Sometimes parents or guardians try to help with homework and, if they have been taught differently, it can end up being confusing for the child doing the homework. They can also end up doing too much of the work themselves!

"Teachers set homework for you to get better at your learning - that seems like a really good reason. But actually, the evidence isn't clear that even that's true."

Another expert Rosamond McNeil, from a teachers' organization called the NUT, said: 'Pupils in Finland are assigned very little homework yet they remain one of the most educationally successful countries in the world." from: BBC NewsRound

After reading:

Take into consideration the following words for the next task.

$\begin{array}{lll}\text { Homework } & \text { Skills } & \\ \text { Stress } & \text { Discipline } & \\ \text { Extra work Activities } & \text { Pressure } & \\ \text { Children } & \text { Unnecessary } & \text { Confusing } \\ \text { Learning } & \text { Teacher } & \text { Primary School } \\ \text { Practice } & \text { Parents } & \text { Support }\end{array}$

According to the information that you gathered, build your own for or against argument related to homework.

Let's Debate

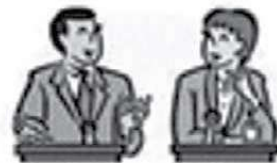

...A Systems of Equations Activity to get Studens to Analyze Methods
5. Now that you have your own arguments in mind, express them in a debate session. Remember that all the arguments have an important value, so be respectful at the moment of arguing. 
Ángela Vanesa Duarte Infante, Sandra Milena Fonseca Velandia, and Bertha Ramos Holguín

After having expressed your arguments and listened to your partners, think the following question over: How could you change the traditional homework concept at school if you were a teacher?

\section{Remember!}

An argument of authority is a form of defeasible argument in which a claimed authority's support is used as evidence for an argument's conclusion. It is well known as a fallacy, though it is used in a cogent form when all sides of a discussion agree on the reliability of the authority in the given context.

question over: How could you change the traditional homework concept at school if you were a teacher?

These are the five parts of an argument: claim, reasons, evidence, warrant, acknowledgement and response 
Debates about Educational Issues: A Pedagogical Strategy to Explore Argumentative Skills in the EFL Classroom

\begin{tabular}{|l|l|}
\hline What is a claim? & $\begin{array}{l}\text { What your argument is based on and a statement } \\
\text { that readers do not already accept it and } \\
\text { will not accept it without good reason. }\end{array}$ \\
\hline What are reasons? & $\begin{array}{l}\text { Support your claim and its statements that give } \\
\text { readers a basis for accepting your claim. }\end{array}$ \\
\hline What is evidence? & $\begin{array}{l}\text { Statements that support your reasons. It is statements, } \\
\text { numbers, photographs, and other representations } \\
\text { of states of affairs that your readers accept without } \\
\text { question, at least for the purposes of an argument }\end{array}$ \\
\hline What is a warrant? & $\begin{array}{l}\text { The general principle usually drawn from } \\
\text { background knowledge shared by you and your } \\
\text { reader that connects your reasons to your claim. }\end{array}$ \\
\hline $\begin{array}{l}\text { What is it acknowledgement } \\
\text { and response? }\end{array}$ & $\begin{array}{l}\text { When the reader has counterclaims you must } \\
\text { acknowledge the reader's skepticism and respond to it. }\end{array}$ \\
\hline
\end{tabular}

Note. Information taken from Quizlet (2018). The five parts of the argument. Retrieved from https://quizlet. com/65870528/the-5-parts-of-an-argument-flash-cards 